\title{
Electrophoretic Patterns of Proteins in the Genus Bifidobacterium and Proposal of Four New Species
}

\author{
B. BIAVATI, ${ }^{1}$ V. SCARDOVI, ${ }^{1}$ AND W. E. C. MOORE ${ }^{2}$ \\ Istituto di Microbiologia Agraria, Universită di Bologna, Bologna, Italy, ${ }^{1}$ and Department of Anaerobic \\ Microbiology, Virginia Polytechnic Institute and State University, Blacksburg, Virginia $2406 I^{2}$
}

The polyacrylamide gel electrophoretic patterns of soluble cellular proteins from 1,094 strains of bifidobacteria were compared with available deoxyribonucleic acid (DNA)-DNA homology data and with the phenotypic and biochemical reactions of these strains. There was excellent correlation between the 25 distinct protein patterns and 24 DNA-DNA homology groups in the genus. Differentiation among species on the basis of common phenotypic properties often was unreliable. Our results demonstrate that the species previously known as "Bifidobacterium eriksonii" is a synonym of Bifidobacterium dentium Scardovi and Crociani; that "Actinomyces parabifidus" is a synonym of Bifidobacterium infantis Reuter; that Bifidobacterium globosum (ex Scardovi, Trovatelli, Crociani, and Sgorbati 1969) sp. nov., nom. rev. (type strain, ATCC 25865) and Bifidobacterium pseudolongum Mitsuoka are closely related but distinct entities; and that Bifidobacterium minimum sp. nov. (type strain, ATCC 27538) and Bifidobacterium subtile sp. nov. (type strain, ATCC 27537) are valid species. Our analyses also indicate that Bifidobacterium coryneforme (ex Scardovi and Trovatelli 1969) sp. nov., nom. rev. (type strain, ATCC 25911) is a valid species. A group of strains intermediate between $B$. infantis and $B$. longum, "Bifidobacterium infantislongum," occurs in calf feces. Identical or nearly identical protein patterns were produced by strains that had $80 \%$ or greater DNA homology.

Among the 20 species of the genus Bifidobacterium cited on the Approved Lists of Bacterial Names (33), several genetically distinct species from humans and other animals cannot be differentiated reliably by commonly used enzymatic or fermentation reactions (5) or by zymograms of transaldolases and 6-phosphogluconate dehydrogenases (23). Several authors have reported the use of polyacrylamide gel electrophoresis (PAGE) of soluble cellular proteins to distinguish species or serovars (serotypes) of bacteria $(1,4,8,9,11,32,35)$ or to determine the similarity of unidentified isolates (15). The present study was designed to determine the reliability and sensitivity of a PAGE procedure (15) to distinguish genetically related and unrelated species of bifidobacteria. For this purpose we compared the electrophoretograms of Bifidobacterium type strains and many other strains that were previously identified according to their deoxyribonucleic acid (DNA)-DNA homology characteristics or phenotypic characteristics or both.

\section{MATERIALS AND METHODS}

Bacterial strains. The strains examined are listed in Table 1.

Methods. The biochemical properties of the strains were determined by methods previously described by
Holdeman et al. (5). The DNA-DNA homology values used were from previously published data $(10,23,24$, $26,27,29-31,37,38$ ) and were obtained by the methods described by Scardovi et al. $(24,29)$.

For electrophoretic analyses, cells were inoculated into $5 \mathrm{ml}$ of supplemented brain heart infusion broth (5) containing $0.1 \%$ calcium carbonate and $0.025 \%$ (final concentration) Tween 80 and then incubated at $37^{\circ} \mathrm{C}$ for $24 \mathrm{~h}$. Growth was harvested by centrifugation at $8,000 \times g$ for $10 \mathrm{~min}$. Electrophoretic analysis of cellular soluble proteins was performed by using the procedures of Moore et al. (15). The similarity of patterns on different gels was determined by placing cut photographs adjacent to each other. Strains with similar protein patterns were reanalyzed on single gels for direct visual comparisons.

\section{RESULTS AND DISCUSSION}

The DNA-DNA homology relationships among species of the genus Bifidobacterium have been studied extensively. Many of the species show close genetic relationships, and several species have similar phenotypic characteristics. Therefore, the species in this genus provide an ideal test of the sensitivity and reliability of the application of PAGE to differentiate bacterial species.

The available type strains and other strains of bifidobacteria that have known DNA homologies with the type strains were included in the 
TABLE 1. Species, number of strains and sources of 1094 bifidobacteria examined by electrophoresis

B. adolescentis:

292 Adult human intestine and feces 19 Sewage

B. angulatum:

5 Sewage

1 Adult human intestine

B. animalis :

4 Chicken feces

4 Rat feces

1 Rabbit feces

1 Sewage

B. asteroides:

8 Bee intestine

B. bifidum:

21 Adult human intestine and feces

14 Human infant feces

5 Human vagina

2 Calf feces

2 Human clinical:

1 Culdocentesis fluid

1 Pancreatic fluid

B. boum

6 Bovine rumen

2 Piglet feces

B. breve

12 Human adult intestine and feces

8 Human infant feces

5 Human clinical:

3 Peritoneal fluid

1 Rectal abscess

1 Colostomy

3 Human vagina

3 Unlisted

1 Calf feces

B. catenulatum:

175 Adult human intestine and feces

15 Sewage

1 Human infant feces

1 Human vagina

1 Unlisted

B. cboerinum:

8 Piglet intestine

2 Sewage

"B. coryneforme":

6 Bee intestine

B. cuniculi:

5 Rabbit feces

B. dentium:

30 Human clinical:

2 Dental abscess

3 Sputum

4 Oral cavity

5 Abdominal wound

1 Ascitic fluid

5 Lung abscess

2 Chest fluid

1 Chest incision

2 Jaw abscess

2 Neck abscess

2 Leg wound

1 Wound
B. dentium (cont'd)

24 Human dental plaque

14 Adult human intestine and feces

5 Unlisted

2 Human vagina

2 Human infant feces

2 Rabbit feces

"B. globosum":

2 Lamb feces

2 Bovine rumen

2 Calf feces

2 Rabbit feces

1 Rat feces

1 Human infant feces

1 Sewage

B. indicum:

9 Bee intestine

B. infantis:

16 Human infant feces

3 Unlisted

1 Human cervix

1 Dog feces

1 Chicken feces

" $B$. infantis-longum":

5 Calf feces

B. longum:

264 Adult human intestine and feces

7 Human clinical:

2 Blood

1 Umbilicus

1 Abdominal cavity

1 Perirectal abscess

1 Renal

1 Placenta

4 Human infant feces

B. magnum

10 Rabbit feces

"B. minimum":

2 Sewage

B. pseudocatenulatum:

3 Human infant feces

3 Calf feces

1 Sewage

B. pseudolongum:

3 Swine feces

1 Sewage

B. pullorum:

3 Chicken feces

"B. subtile":

5 Sewage

B. suis :

7 Piglet intestine and feces

B. thermophilum:

13 Piglet stomach

2 Piglet feces

4 Bovine rumen

1 Calf feces

2 Sewage 
TABLE 2. Published DNA homology relationships of Bifidobacterium species

\begin{tabular}{|c|c|c|}
\hline $\begin{array}{l}\text { Species } \\
\text { (literature citation) }\end{array}$ & $\begin{array}{l}\% \text { of homology } \\
\text { within (range) }\end{array}$ & Comments \\
\hline B. adolescentis (21) & $70-102(24)$ & Below $50 \%$ homology with all the other species ${ }^{a}$ \\
\hline B. angulatum (24) & $76-95(24)$ & Below $50 \%$ homology with all the other species ${ }^{a}$ \\
\hline B. animalis $(12,26)$ & $72-99(26)$ & Below $50 \%$ homology with all the other species ${ }^{a}$ \\
\hline B. asteroides (25) & Not published & $50 \%$ homology with B. choerinum (27) \\
\hline B. bifidum $(17,36)$ & $100(29)$ & Below $50 \%$ homology with all the other species ${ }^{a}$ \\
\hline B. boum (27) & $69-96(27)$ & Closely related to B. thermophilum at $60-70 \%$ (27) \\
\hline B. breve (21) & $75-100(29)$ & $\begin{array}{l}\text { Closely related to } B \text {. infantis and } B \text {. longum at } \\
50-75 \%(23)\end{array}$ \\
\hline B. catenulatum (24) & $78-101(27)$ & $\begin{array}{l}\text { Closely related to B. pseudocatenulatum at } 60-80 \% \\
\text { (27) }\end{array}$ \\
\hline B. choerinum (27) & $75-120(27)$ & $\begin{array}{l}50 \% \text { homology with "B. globosum", B. pseudo- } \\
\text { longum, and B. asteroides ( } 27)\end{array}$ \\
\hline "B. coryneforme" (25) & Not published & Closely related to B. indicum at $60 \%(31)$ \\
\hline B. cuniculi (27) & $94-102(27)$ & Closely related to B. globosum at $50-67 \%$ (27) \\
\hline B. dentium (24) & $69-110(24)$ & Below $50 \%$ homology with all the other species ${ }^{a}$ \\
\hline "B. globosum" (28) & $\begin{array}{l}78-106(29) \\
72-104(38)\end{array}$ & Closely related to B. pseudolongum at $69-73 \%$ (29) \\
\hline B. indicum $(25)$ & Not published & Closely related to $B$. coryneforme at $60 \%$ (31) \\
\hline B. infantis (21) & Not published & Closely related to $B$. longum at $65-80 \%$ (23) \\
\hline "B. infantis-longum" & Not published & $\begin{array}{l}\text { Over } 80 \% \text { related to the reference strains of } B \text {. } \\
\text { infantis and } B \text {. longum (23) }\end{array}$ \\
\hline B. longum (21) & Not published & Clbsely related to $B$. infantis at $65-80 \%$ (23) \\
\hline B. magnum (30) & $75-106(30)$ & Below $50 \%$ homology with all the other species ${ }^{a}$ \\
\hline B.pseudocatenulatum (27) & $78-115(27)$ & Closely related to $B$. catenulatum at $60-80 \%$ (27) \\
\hline B. pseudolongum (12) & Not published & Closely related to B. globosum at $69-73 \%$ (29) \\
\hline B. pullorum (37) & $94-107(37)$ & Below $50 \%$ homology with all the other species ${ }^{a}$ \\
\hline B. suis $(10)$ & $100(10)$ & Below $50 \%$ homology with all the other species ${ }^{a}$ \\
\hline B. thermopbilum (12) & $79-117(27)$ & Closely related to $B$. boum at $60-70 \%$ (27) \\
\hline "B. minimum" (26) & $103(26)$ & Below $50 \%$ homology with all the other species ${ }^{a}$ \\
\hline "B. subtile" (26) & $70-94(26)$ & Below $50 \%$ homology with all the other species ${ }^{a}$ \\
\hline
\end{tabular}

\footnotetext{
${ }^{a}$ Differentiation of this species from all other species is indicated in several references which provide one or more comparisons $(10,24,26,27,29,30,31,37)$.
}

PAGE study. To facilitate comparisons of the DNA homology and PAGE results, a summary (primarily from previously published work) of the DNA-DNA relationships of these strains and species is presented in Table 2 .

Electrophoretic patterns of soluble cellular proteins. The distinctive protein patterns of the type strains (and strains that are known to have high DNA homology with the type strains) correlated with the DNA homology relationships among the bifidobacteria and were found to be repeat- able (see Fig. 1, lane 8; Fig. 2, lane 13; and Fig. 12, lane 2). This PAGE procedure (15) was highly sensitive and could distinguish between species that have less than $\mathbf{8 0 \%}$ interspecies DNA-DNA homology. Within species, strains that have $80 \%$ or greater homology had identical, or nearly identical, protein patterns.

The PAGE patterns of 1,094 Bifidobacterium strains were determined and compared with the patterns of the type strains of the Bifidobacteri$u m$ species and with the patterns of strains that 


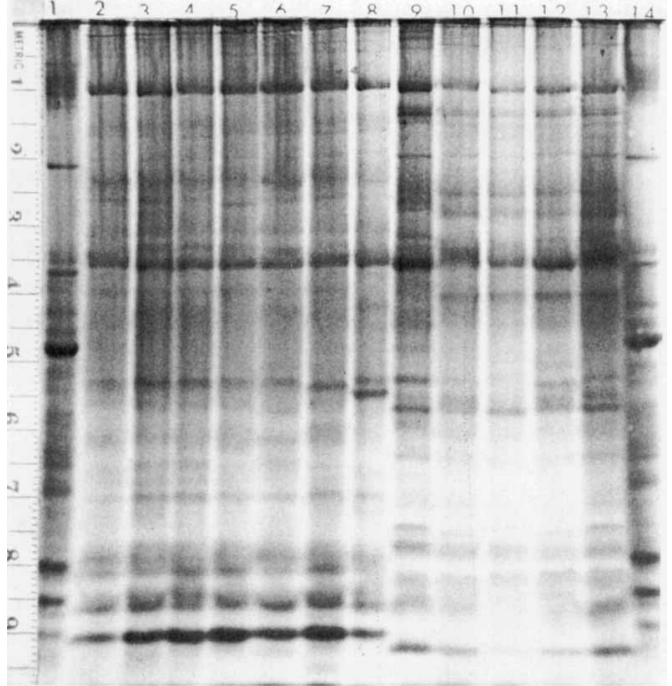

FIG. 1. B. adolescentis, lanes 2 to $8: 2=\mathrm{VPI}$ A3-27B, feces, adult rural South African black; 3 = VPI B6-42, feces, adult Caucasian, U.S.; 4 = VPI C8-1, feces, adult Japanese-Hawaiian; 5 = VPI J1-2, feces, adult rural Japanese; $6=$ VPI M3-140, adult human stomach contents, U.S.; 7 = VPI 7501 (Scardovi F351), waste water, Italy; 8 = ATCC 15703 (type strain), intestine of adult human, Germany.

B. angulatum, lanes 9 to $13: 9=\mathrm{ATCC}$ 27535 (type strain), human feces, Italy; $10=$ ATCC $27669,11=$ ATCC 27670, $12=$ ATCC 27671,13 = VPI 7569 (Scardovi F426), all from waste water, Italy.

are known to have high DNA homology with the type strains. The PAGE patterns of representative strains of Bifidobacterium species are shown in Fig. 1 to 14 . For each species, the strains chosen as representatives included the type strain and the strains from the most widely divergent sources that were available in order to illustrate the maximum variation among strains within each species. When possible, species that are closely related by DNA-DNA homology, species with similar phenotypic properties, and species from similar habitats (in that order) were placed on the same gel to test the sensitivity of the electrophoretic analysis.

On all gels, lanes 1 and 14 show the reference patterns of Streptococcus faecalis strain VPI U4-20, which was used as a control for detecting gel-to-gel variation. The two major causes of variation in gel density were the moisture content of the gel powder (which affected the actual amount of acrylamide weighed) and the oxygen content of the gel solution. Complete removal of the oxygen (e.g., with iron) from the acrylamide solution caused immediate solidification when persulfate was added, and the gels could not be poured. Mechanical removal of oxygen under reduced pressure left variable amounts of oxygen in solution. Other causes of variation are under investigation.

From the $S$. faecalis control strain, the dark band that appears between 43 and $49 \mathrm{~mm}$ is a useful reference point for comparing different gels. The band at $1 \mathrm{~cm}$ is typical of most species of the genus Bifidobacterium.

Patterns from Bifidobacterium adolescentis and Bifidobacterium angulatum strains are shown in Fig. 1. Cultures of the type strain of $B$. adolescentis (Fig. 1, lane 8 ) have a band at 54 $\mathrm{mm}$ that is reproducible (see Fig. 2, lane 13, and Fig. 12, lane 2), as are most of the other minor variations in banding patterns among strains

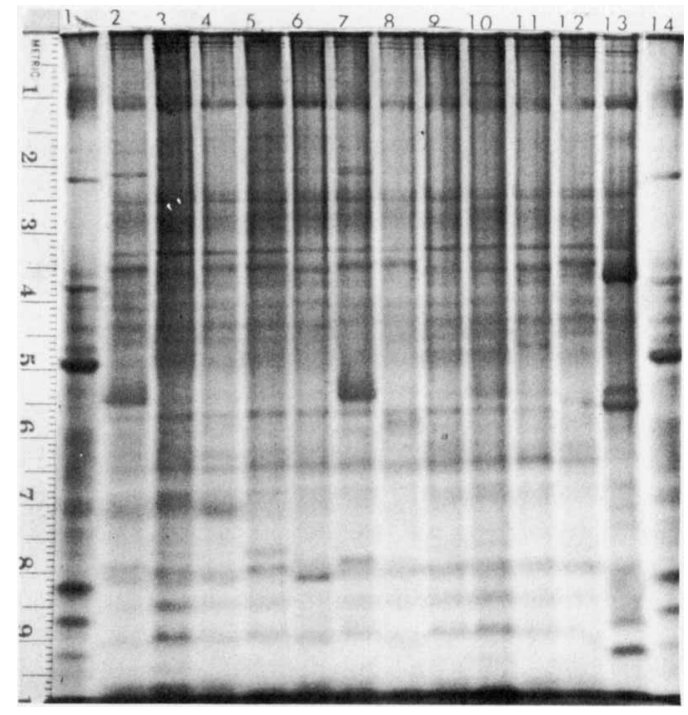

FIG. 2. B. dentium, lanes 2 to $8: 2=$ ATCC 27678, adult human feces, Italy; $3=$ ATCC 27679, human vagina, Italy; $4=$ ATCC 27680 , human dental caries, Italy; 5 = VPI 0661 (CDC 1209B-1), human autopsy lung tissue, U.S.; 6 = VPI 13250 (Scardovi B2617), human infant feces, Italy; 7 = VPI 13251 (Scardovi Ra116), rabbit feces; $8=$ ATCC 27534 (type strain), human dental caries, Italy.

B. dentium ("B. eriksonii"), lanes 9 to $12: 9$ = ATCC 15424 (labeled $B$, adolescentis, CDC X407 ["A. eriksonii"], pleural fluid, adult male), presumably U.S.; $10=$ VPI 1932 (CDC $\mathrm{X} 685$, originally labeled " $A$. eriksonii"); $11=$ ATCC 15423 (labeled $B$. adolescentis, CDC $\mathrm{X} 573$, [originally the type strain of " $A$. eriksonii"] ), lung abscess, adult male; $12=$ VPI 1935 (CDC X425 "A. eriksonii"), human abscess.

B. adolescentis, lane $13=$ ATCC 15703 (type strain). 


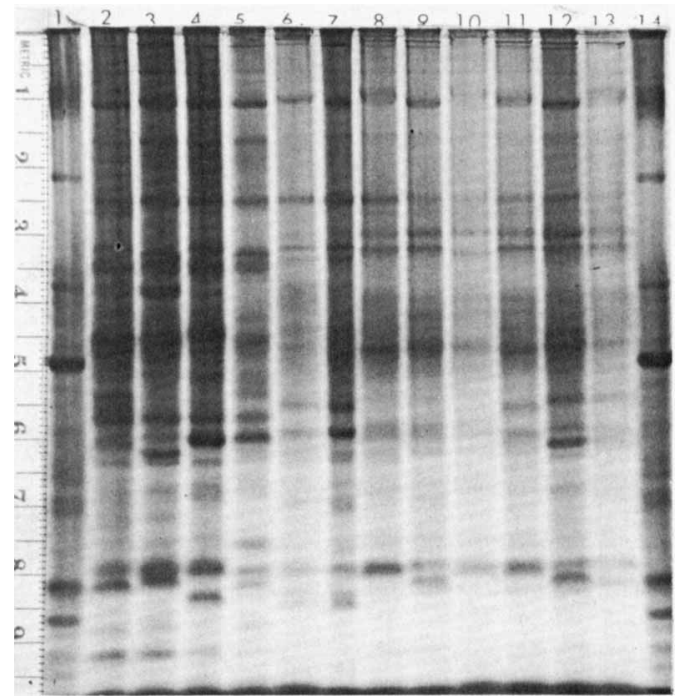

FIG. 3. B. infantis, lanes 2 to $5: 2=$ ATCC 15697 (type strain), human infant feces, Germany; $3=$ ATCC 25962, human infant feces, Germany; $4=$ ATCC 15702, human infant feces, Germany; $5=$ ATCC 17930 (labeled B. bifidum CDC W723, [Actinomyces parabifidus] Strain Timberland [19]; L. Pine $308[3,20])$.

" $B$. infantis-longum" (an intermediate "biotype' between $B$. infantis and $B$. longum by DNA homology, fermentation reactions, and electrophoretic pattern), lanes 6 and $7: 6=\mathrm{VPI}$ 13294 (Scardovi VT420), calf feces; $7=\mathrm{VPI}$ 13295 (Scardovi VT302), calf feces.

B. longum, lanes 8 to $12: 8=$ ATCC 15707 (type strain), adult human intestine, Germany; $9=$ VPI R1-33, adult human feces, U.S.; $10=$ VPI J8-25, adult human feces, rural Japan; $11=$ VPI X2-30, adult human feces, U.S.; 12 = VPI M3-122, adult human stomach contents; $13=$ VPI 7269, human infant feces, U.S.

within the species. This species is commonly isolated from the intestines and feces of adult humans, but it was not found in any fecal samples from more than 100 infants in Italy.

In addition to the "genus band" at $1 \mathrm{~cm}$, strains of $B$. adolescentis and $B$. angulatum share a band at $36 \mathrm{~mm}$ and show strain-to-strain variation with bands at 53 to $57 \mathrm{~mm}$. Close inspection reveals several bands that are uniformly distinct for the two species.

The PAGE patterns of Bifidobacterium dentium and $B$. adolescentis strains are shown in Fig. 2. B. dentium Scardovi and Crociani 1974, B. adolescentis Reuter 1963, and "Actinomyces eriksonii" Georg et al. 1965 have very similar fermentation patterns (see Table 5). B. dentium and $B$, adolescentis are distinct species according to the results of DNA homology studies (24) and have distinct PAGE patterns. The PAGE patterns of $B$. dentium and "Bifidobacterium eriksonii" ("A. eriksonii') are very similar. The taxonomic status of "A. eriksonii" has changed several times since the species was first described. Because of the similarity between " $A$. eriksonii" and bifidobacteria, the species was designated ' $B$. eriksonii'" by Holdeman and Moore (7). In 1974, Mitsuoka et al. (13) studied the cultural and phenotypic reactions of $B$. adolescentis and " $B$. eriksonii" and considered the two species to be identical. "A. eriksonii" is listed as a species incertae sedis in Bergey's Manual of Determinative Bacteriology, 8th ed. (34), and the name was not included on the Approved Lists of Bacterial Names (33), apparently because it was assumed to be a later synonym of $B$. adolescentis. Scardovi et al. (23)

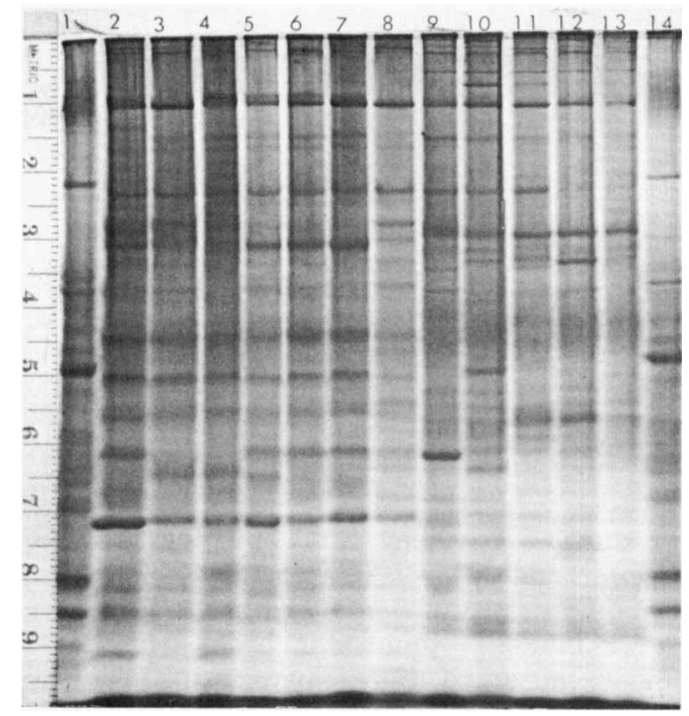

FIG. 4. B. bifidum (type species of the genus), lanes 2 to 8: 2 = VPI M4-361, adult human ascending colon; $3=$ VPI S5E-45, adult human feces (after all-meat diet for 3 days), U.S.; 4 = ATCC 15696, human infant intestine, Germany; 5 = VPI 5645 (Scardovi B790), human vagina, Italy; $6=$ VPI 13223 (Scardovi VT181), calf feces, Italy; $7=$ VPI 12064 , human pancreatogram fluid, U.S.; $8=$ ATCC 29521 (type strain), Tissier's strain from the Prevot collection, human infant feces, France.

$B$. breve, lanes 9 to $13: 9=$ ATCC 15700 (type strain), human infant feces, Germany; 10 = VPI C11-10, adult Japanese-Hawaiian feces, Hawaii; 11 = ATCC 15698, human infant intestine, Germany; $12=$ VPI 5642 (Scardovi B720), human vagina, Italy; $13=$ VPI 13234 (Scardovi VT268), calf feces, Italy. 


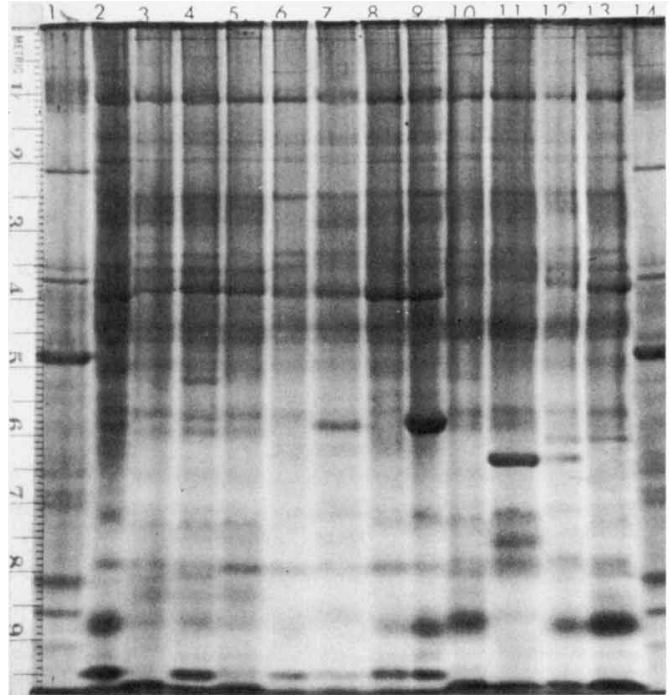

FIG. 5. B. catenulatum, lanes 2 to $9: 2=$ VPI M3-204, duodenum contents, adult human black, U.S.; 3 = VPI J4-38, adult human feces, rural Japan; 4 = VPI 7399A (Scardovi B618), human infant feces, Italy; $5=$ VPI 6276 , human vagina, U.S.; $6=$ ATCC 27675 , adult human feces, Germany; 7 = VPI 7495 (Scardovi F64), sewage, Italy; 8 = VPI C52-40B, adult JapaneseHawaiian feces, Hawaii; $9=$ ATCC 27539 (type strain), adult human feces, Italy.

B. pseudocatenulatum, lanes 10 to $13: 10=$ ATCC 27919 (type strain), human infant feces, Italy; 11 = VPI 13270 (Scardovi B1460), human infant feces, Italy; $12=$ VPI 13275 (Scardovi VT74), calf feces, Italy; 13 = VPI 13276 (Scardovi F54), sewage, Italy.

reported 80 to $100 \%$ DNA homology among ATCC 27534 (the type strain of $B$. dentium), ATCC 15423 ("A. eriksonii"), and ATCC 15424, the type strain of " $A$. eriksonii." The nearly identical electrophoretic patterns of the strains of $B$. dentium and " $B$. eriksonii" further confirm the reliability of the PAGE results and the synonymy of " $B$. eriksonii" with $B$. dentium rather than with $B$. adolescentis. The name $B$. dentium is retained because neither " $A$. eriksonii" nor "B. eriksonii" appeared on the Approved Lists and therefore the earlier names have no taxonomic standing and cannot be considered earlier synonyms of $B$. dentium.

The electrophoretic patterns of soluble proteins of Bifidobacterium infantis, Bifidobacterium longum, and an intermediate group labeled "Bifidobacterium infantis-longum" are shown in Fig. 3. Included with $B$. infantis is ATCC 17930 (lane 5), which was once labeled "Actinomyces parabifidus." Although "A. parabifidus"

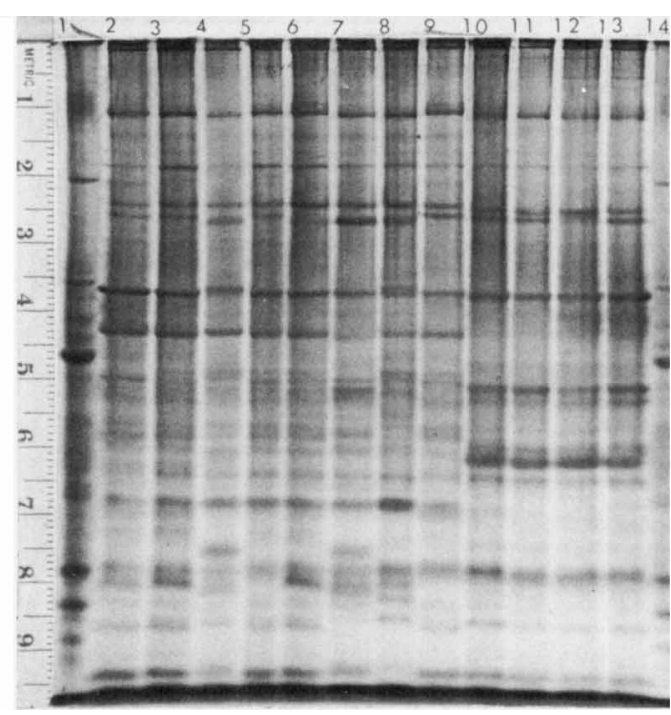

FIG. 6. "B. globosum", lanes 2 to $9: 2=$ ATCC 25865 (type strain), bovine rumen, Italy; 3 = VPI 13379 (Scardovi Ag40), lamb feces, Italy; 4 = VPI 13384 (Scardovi F229), sewage, Italy; 5 = VPI 13386 (Scardovi B607), human infant feces, Italy; $6=$ VPI 13389 (Scardovi VT376), calf feces, Italy; $7=$ VPI 13390 (Scardovi T15), rat feces, Italy; $8=$ VPI 13392 (Scardovi Ra120), rabbit feces, Italy; $9=$ ATCC 25864 , bovine rumen, Italy.

B. pseudolongum, lanes 10 to $13: 10=$ ATCC 25526 (type strain), swine feces, Japan; 11 = VPI 13382 (Scardovi Su841), piglet feces, Italy; 12 = VPI 13383 (Scardovi Su914), piglet feces, Italy; 13 = VPI 13385 (Scardovi F468), sewage, Italy.

was reported to be synonymous with Bifidobacterium bifidum $(18,22)$, ATCC 17930 has neither the biochemical reactions nor the electrophoretic pattern of $B$. bifidum. However, this strain does have the phenotypic characteristics and protein pattern of $B$. infantis, and we have determined that it has $82 \%$ DNA-DNA homology with ATCC 27920 , the reference strain of $B$. infantis. It also has $76 \%$ DNA-DNA homology with the type strain of B. longum. A close relationship to $B$. longum is characteristic of all of the strains of $B$. infantis studied.

With respect to its fermentation reactions (see Table 5), B. infantis is similar to $B$. adolescentis and Bifidobacterium catenulatum, but no strain of $B$. infantis (as determined by electrophoretic protein patterns or by DNA-DNA homology) has been found in feces of adult humans. $B$. infantis has been found in human vaginas and, as previously reported, in feces from infants. Strains previously reported as $B$. infantis from 


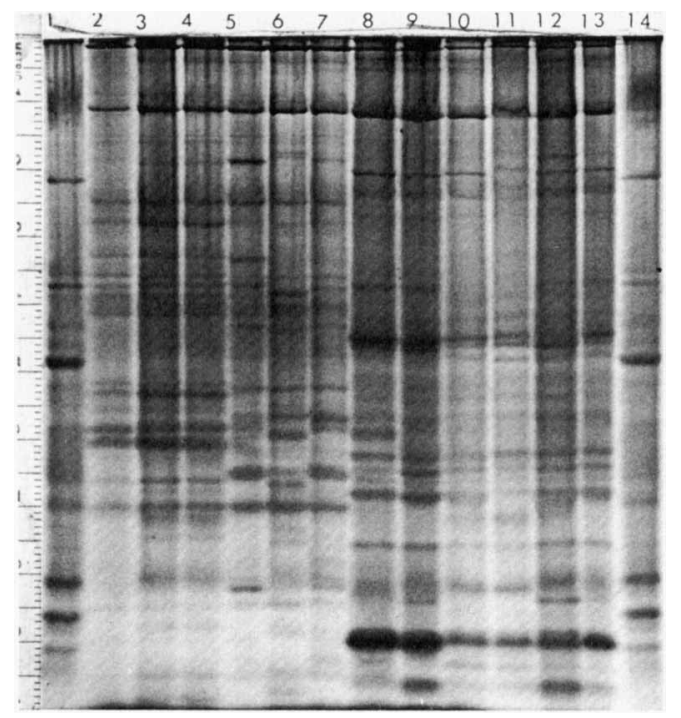

FIG. 7. B. animalis, lanes 2 to $7: 2=$ ATCC 27673, sewage, Italy; $3=$ ATCC 27674 , rabbit feces, Italy; $4=$ ATCC 27536 , chicken feces, Italy; 5 = ATCC 27672, rat feces, Italy; $6=$ VPI 13212 (Scardovi T27), rat feces, Italy; $7=$ ATCC 25527 (type strain), rat feces, Japan.

B. magnum, from rabbit feces, Italy, lanes 8 to $13: 8=$ ATCC 27540 (type strain), $9=$ ATCC $27681,10=$ ATCC $27682,11=$ VPI 13265 (Scardovi Ra89), 12 = VPI 13266 (Scardovi Ra184), 13 = VPI 13268 (Scardovi Ra209).

feces of adult humans $(6,14,16)$ have been reidentified in this study either as $B$. adolescentis or as $B$. catenulatum.

The close genetic relationships among $B$. infantis, B. longum, and the "B. infantis-longum" group (Table 2) and their similar fermentation patterns (see Table 5) are reflected in the similar electrophoretic patterns of their soluble cellular proteins. The similarities suggest that these groups may be subspecies of B. longum. However, bands at $92 \mathrm{~mm}$ (Fig. 3, lanes 2 through 5) and $30 \mathrm{~mm}$ (lanes 8 through 13) appear to be distinctive and to correlate with the strains of $B$. infantis and $B$. longum, respectively, that have greater intragroup DNA homology than intergroup DNA homology.

The electrophoretic patterns of B. bifidum and Bifidobacterium breve are shown in Fig. 4. B. bifidum is among the most easily recognized species in the genus because of its characteristic fermentation pattern (see Table 5). The heavy band at $62 \mathrm{~mm}$ produced by the type strain of $B$. breve (Fig. 4, lane 9) varies with the age of the culture and is sometimes present in other strains of the species.
The electrophoretic patterns of $B$. catenulatum and Bifidobacterium pseudocatenulatum are shown in Fig. 5. These two species are closely related and share 60 to $80 \%$ DNA-DNA homology. They reportedly differ in the guanineplus-cytosine contents of their DNAs ( $B$. catenulatum, $54.7 \mathrm{~mol} \%$; B. pseudocatenulatum, 57.5 mol\% $[24,27])$, cell wall peptidoglycan (O. Kandler, personal communication), and isozyme patterns (23). Although a band at $95 \mathrm{~mm}$ appears to correlate with $B$. catenulatum strains, differentiation on the basis of electrophoretic protein patterns is questionable. The DNA homology and protein similarities suggest that $B$. catenulatum and $B$. pseudocatenulatum may be subspecies of $B$. catenulatum.

The patterns of "Bifidobacterium globosum" Scardovi et al. 1969 (not on the Approved Lists [33]) and Bifidobacterium pseudolongum are shown in Fig. 6. These two species share about $70 \%$ DNA-DNA homology (see Table 2) and have the same fermentation patterns; their names are considered by Rogosa (22) to be synonyms. However, the reported guanine-plus-

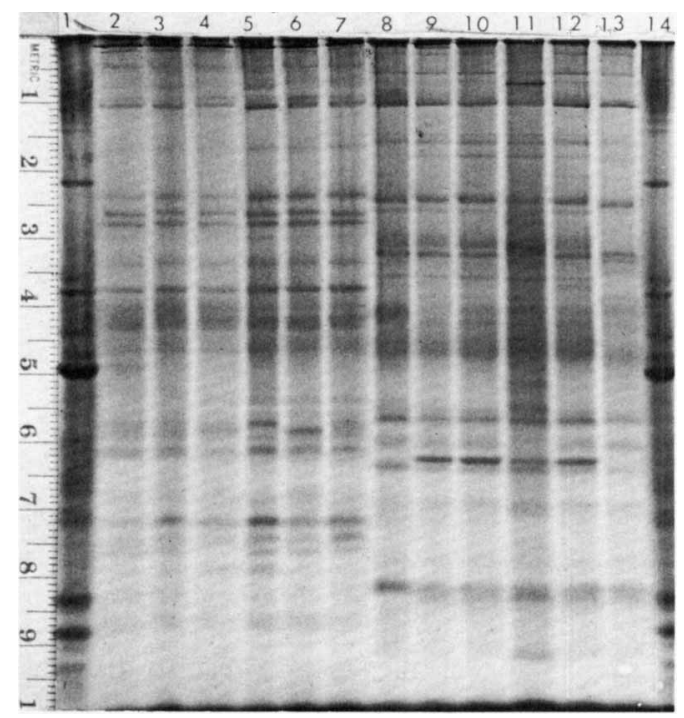

FIG. 8. B. choerinum, lanes 2 to $7: 2=$ VPI 13235 (Scardovi Su827), piglet feces, Italy; $3=$ VPI 13237 (Scardovi Su837), piglet feces, Italy; 4 = VPI 13239 (Scardovi Su882), piglet feces, Italy; 5 = VPI 13242 (Scardovi F 390), sewage, Italy; 6 = VPI 13243 (Scardovi F441), sewage, Italy; 7 = ATCC 27686 (type strain), piglet feces, Italy.

B. suis, from piglet feces, Italy, lanes 8 to 13: $8=$ ATCC $27533,9=$ ATCC $27531,10=$ ATCC 27532, $11=$ VPI 13281 (Scardovi Su889), 12 = VPI 13282 (Scardovi Su940), 13 = VPI 13284 (Scardovi Su850). 


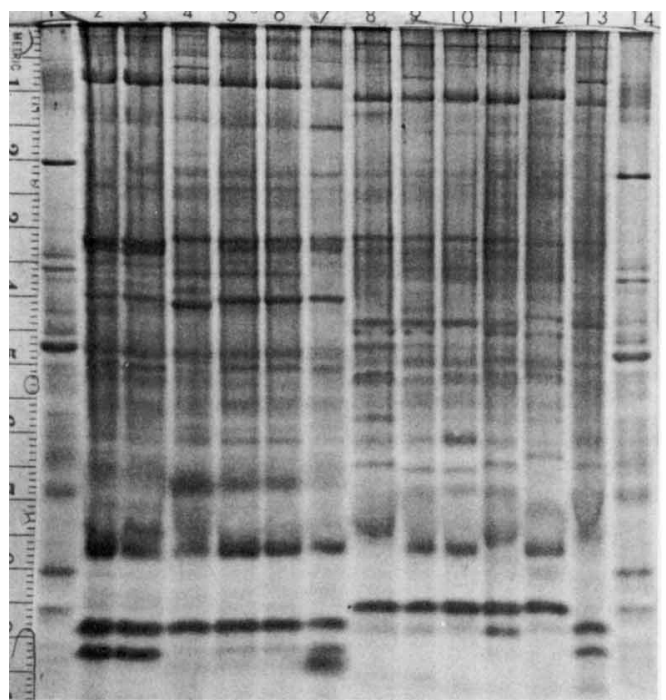

FIG. 9. B. boum, lanes 2 to $7: 2=$ VPI 13224 (Scardovi Ru246), bovine rumen, Italy; 3 = VPI 13225 (Scardovi Ru276), bovine rumen, Italy; 4 = VPI 13226 (Scardovi Ru400), bovine rumen, Italy; 5 = VPI 13231 (Scardovi Su910), piglet feces, Italy; $6=$ VPI 13232 (Scardovi Su912), piglet feces, Italy; 7 = ATCC 27917 (type strain), bovine rumen, Italy.

B. thermophilum, lanes 8 to $13: 8=$ ATCC 25525 (type strain), swine feces, Japan; $9=$ ATCC 25866, bovine rumen, Italy; $10=$ ATCC 25867, bovine rumen, Italy; $11=$ VPI P10A-4, piglet feces, U.S.; 12 = VPI 13288 (Scardovi F539), sewage, Italy; 13 = VPI 13291 (Scardovi VT95), calf feces, Italy.

cytosine contents of their DNAs differ by 3 mol\% (29), and the two nomenspecies were considered to be distinct entities by Scardovi et al. (29). The electrophoretic patterns indicate that these two groups can be recognized as distinct, but closely related, species. Therefore, we propose revival of the name $B$. globosum (see below).

The PAGE patterns of strains of Bifidobacterium animalis and Bifidobacterium magnum are shown in Fig. 7. The B. animalis strains from rats (Fig. 7, lanes 5 through 7) appear to be highly specific and different from the strains from sewage, rabbits, and chickens. In addition to DNA-DNA homology and electrophoretic protein pattern differences, $B$. magnum is also distinguished by its unusually large cellular dimensions (30).

Electrophoretograms of two species commonly isolated from swine are shown in Fig. 8. Although Bifidobacterium choerinum and Bifidobacterium suis are both common in swine feces, these two species show little or no DNA-

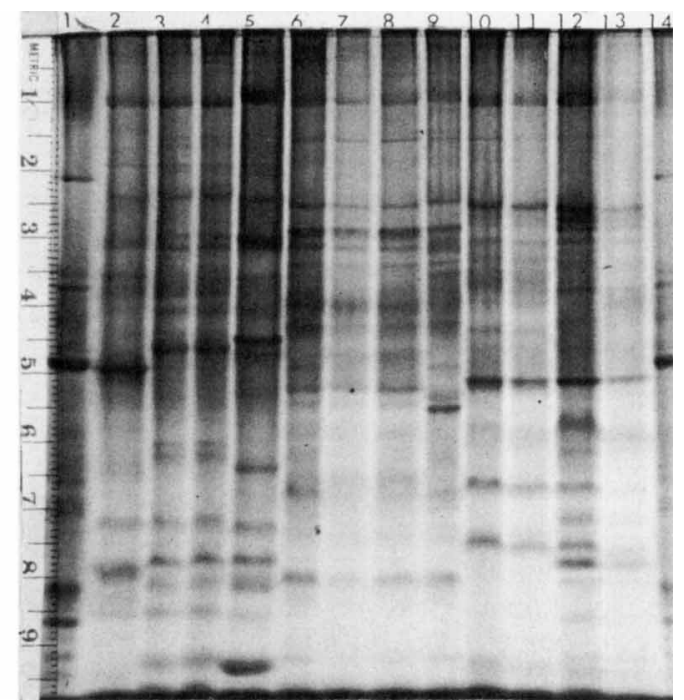

FIG. 10. B. asteroides, from intestines of honey bees (Apis mellifera), lanes 2 to $5: 2=$ VPI 13216 (Scardovi C229), Norway; 3 = VPI 13217 (Scardovi C391), Czechoslovakia; 4 = VPI 13219 (Scardovi 395), Czechoslovakia; 5 = ATCC 25910 (type strain), Italy.

$B$. coryneforme sp. nov., nom. rev. from intestines of Apis mellifera, lanes 6 to 9:6= ATCC 25911 (type strain), Norway; $7=$ VPI 13303 (Scardovi C216), Norway; $8=$ VPI 13304 (Scardovi C218), Norway; $9=$ VPI 13305 (Scardovi C242), England.

$B$. indicum, from intestines of bees, lanes 10 to 13: $10=$ ATCC 25912 (type strain) from Apis cerana, Malaysia; 11 = VPI 13254 (Scardovi C403), Apis cerana, Malaysia; 12 = VPI 13256 (Scardovi C421) from Apis dorsata, Philippines; 13 = VPI 13257 (Scardovi C435), Apis cerana, Philippines.

DNA homology and have distinct fermentation patterns (see Table 5).

The electrophoretic patterns of Bifidobacterium boum and Bifidobacterium thermophilum are shown in Fig. 9. These two species share 60 to 70\% DNA-DNA homology and are difficult to distinguish on phenotypic bases. However, the protein patterns appear to be distinctive. The genus band at $1 \mathrm{~cm}$ was displaced and appeared at $8 \mathrm{~mm}$ in all cultures of $B$. boum tested. Strain 13291 (Fig. 9, lane 13) is classified as B. thermophilum on the basis of DNA homology. However, this strain has an isozyme with a mobility that is intermediate between that of $B$. thermophilum and that of $B$. boum (23). The intermediate electrophoretic pattern appears to correlate with the isozyme determinations.

The electrophoretic patterns of Bifidobacteri- 
TABLE 3. Percent DNA homology among strains of $B$. asteroides, $B$. indicum, and "B. coryneforme"

\begin{tabular}{lcc}
\hline \multirow{2}{*}{ DNA from } & \multicolumn{2}{c}{ Reference DNA from } \\
\cline { 2 - 3 } & B. asteroides & B. indicum \\
\hline B. asteroides & $100 \%$ & $30 \%$ \\
B. indicum & $33 \%$ & $100 \%$ \\
"B. coryneforme" & $23 \%$ & $60 \%$ \\
\hline
\end{tabular}

um asteroides, "Bifidobacterium coryneforme," and Bifidobacterium indicum, all isolated from honey bees, are shown in Fig. 10. " $B$. coryneforme" (Fig. 10, lanes 6 through 9) was inadvertently omitted from the Approved Lists (33) and therefore currently has no taxonomic standing. This species is distinct from $B$. asteroides and $B$. indicum, as reported by Scardovi et

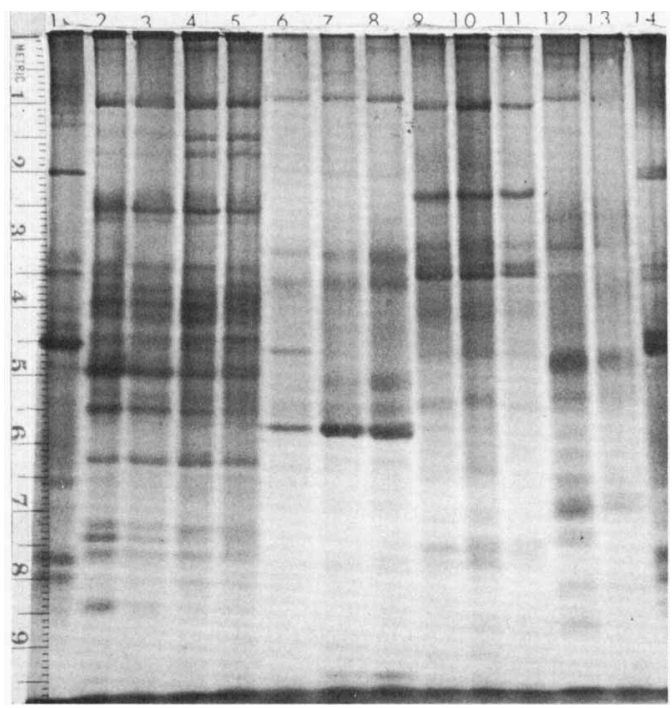

FIG. 11. B. cuniculi, from rabbit feces, Italy, lanes 2 to 5: 2 = VPI 13244 (Scardovi Ra94), 3 = VPI 13245 (Scardovi Ra95), 4 = VPI 13246 (Scardovi Ra98), 5 = ATCC 27916 (type strain).

B. pullorum, from chicken feces, Italy, lanes 6 to $8: 6=$ ATCC 27685 (type strain), $7=$ VPI 13279 (Scardovi P182), 8 = VPI 13280 (Scardovi P183).

B. subtile sp. nov., from sewage, Italy, lanes 9 to $11: 9=$ ATCC $27683,10=$ ATCC 27684 , 11 = ATCC 27537 (type strain).

B. minimum sp. nov., from sewage, Italy, lanes 12 and 13: 12 = VPI 13297 (Scardovi F399), 13 = ATCC 27538 (type strain). al. (31) and as determined by DNA homology (Table 3), and it appears to differ in fermentation reactions as well as cellular proteins. Therefore, we propose reinstatement of the name $B$. coryneforme (see below).

The electrophoretic patterns of Bifidobacterium cuniculi and Bifidobacterium pullorum and of two new species are shown in Fig. 11. A direct comparison of the patterns of the type strains of the various Bifidobacterium species is presented in Fig. 12 and 13.

In the interpretation of the electrophoretic protein patterns, as in all other microbiological work, one is constantly concerned with the possibility that the results may have been affected by contaminants. In some instances, the protein patterns themselves provide evidence of contamination by displaying patterns that are unusual for the species or genus, as illustrated in Fig. 14.

Phenotypic characteristics. A total of 732 isolates of bifidobacteria from adult human feces $(6,14,16)$, from all anatomic areas of adult human and piglet intestinal tracts, and from pig feces were studied. These isolates had been identified previously on the basis of their fermentation patterns. Because the PAGE patterns

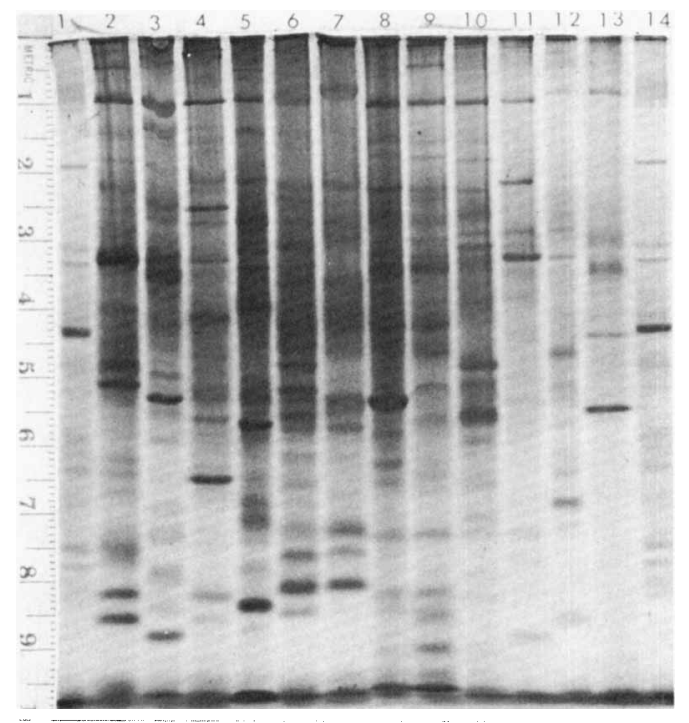

FIG. 12. Electrophoretic patterns of the type strains of 12 species of Bifidobacterium. Lane $2=B$. adolescentis ATCC 15703, $3=B$. angulatum ATCC $27535,4=B$. bifidum ATCC $29521,5=B$. breve ATCC 15700, $6=B$. infantis ATCC $15697,7=B$. longum ATCC $15707,8=B$. catenulatum ATCC $27539,9=$ $B$. pseudocatenulatum ATCC $27919,10=B$. dentium ATCC 27534, $11=B$, subtile ATCC $27537,12=B$. minimum ATCC 27538, $13=B$. pullorum ATCC 27685. 


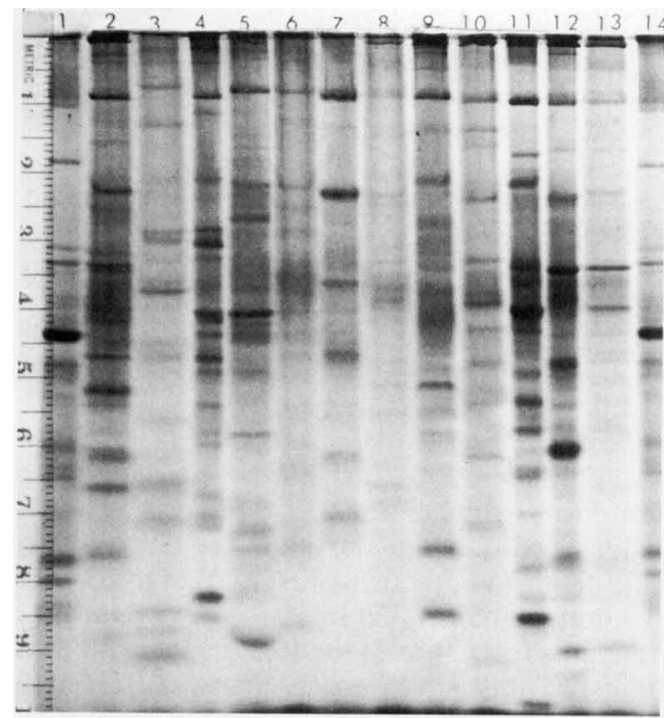

FIG. 13. Type strains of additional species, from animals. Lane $2=B$, animalis ATCC $25527,3=B$. boum ATCC 27917, $4=B$. thermopbilum ATCC 25525, $5=B$, asteroides ATCC $25910,6=B$. coryneforme ATCC $25911,7=B$. indicum ATCC 25912, $8=B$. choerinum ATCC $27686,9=B$. suis $\mathrm{A}$ 'TCC 27533, $10=B$. cuniculi ATCC 27916, $11=B$. magnum ATCC 27540, $12=B$. pseudolongum ATCC 25526, $13=$ B. globosum ATCC 25865.

of type strains and of strains that have high DNA-DNA homology with the type strains were nearly identical, distinct from those of other species, and repeatable, it became obvious that PAGE was more reliable for differentiating Bifidobacterium species than fermentation reactions were. Therefore, the intestinal strains were reidentified according to their protein electrophoretic patterns. The original identifications, which were based on fermentation reactions, and the identifications based on the PAGE patterns are shown in Table 4.

The fermentation reactions of the type strains of the species studied and of the strains identified by PAGE are listed in Table 5. These results were obtained over several years. Improvements in formulations of media during that time might account for some of the phenotypic variations, but variation was observed among different strains in several species even when they were reexamined with our currently used media.

Table 5 shows that several Bifidobacterium species cannot be differentiated reliably on the basis of fermentation reactions. Even the most discriminating tests fail to separate major species of human origin, as shown in Table 6 . The reliability of this key sometimes can be im-

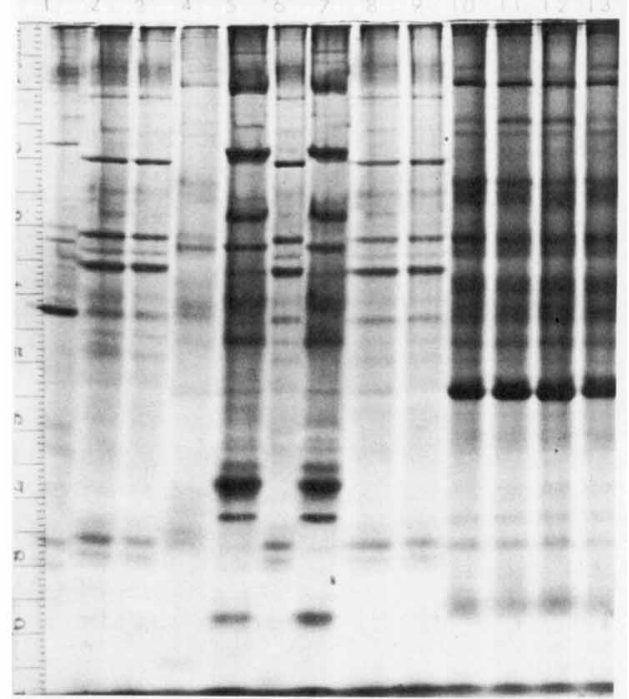

FIG, 14. Results from mixed cultures. Lane 2 = pattern produced by a culture labeled $B$. pseudocatenulatum (the original mixed culture was repeated on this gel for illustrative purposes), $3=$ pure culture of diplococci isolated from original mixed culture, $4=$ pure culture of $B$. pseudocatenulatum derived from the original mixed culture.

Lane $5=$ culture labeled $B$. pseudocatenulatum, 6 = single colony isolate of diplococci derived from the original culture, $7=$ single colony isolate of streptococci derived from the original culture. No bifidobacteria were recovered from this culture.

Lane $\mathbf{8}$ = original culture labeled $B$. pseudocatenulatum (by DNA homology), $9=$ pure culture of diplococci derived from the original culture, 10 through 13 = single colony isolates of bifidobacteria derived from the original culture. The electrophoretic patterns of these isolates (VPI 13278) are most similar to those of $B$. catenulatum.

proved if the source of an unidentified isolate is known (Table 1); nevertheless, only DNA-DNA homology data or PAGE protein patterns appear to provide highly definitive results.

New species. The protein patterns, fermentation reactions, and previously published DNADNA homology data support reinstatement of "B. coryneforme"' Scardovi and Trovatelli and "B. globosum' Scardovi, Trovatelli, Crociani, and Sgorbati and elevation of the "Bifidobacterium minimum" and "Bifidobacterium subtile" homology groups of Scardovi and Trovatelli to the species level. Accordingly, we propose the four new species of Bifidobacterium listed below.

Like other members of the genus Bifidobac- 
TABLE 4. Identification of bifidobacteria by fermentation reactions and by protein electrophoretic patterns

\begin{tabular}{ll}
\hline $\begin{array}{l}\text { Identification by } \\
\text { fermentation }\end{array}$ & $\begin{array}{l}\text { Identification by } \\
\text { electrophoresis }\end{array}$ \\
\hline
\end{tabular}

From humans

$310^{b} B$, adolescentis

202 B. longum

90 B. infantis

156 B. adolescent is

114 B. catenulatum

35 B. longum

5 B. dentium

201 B. longum

1 B. catenulatum

52 B. adolescentis

35 B. catenulatum

3 B. breve

70 B. breve

21 B. bifidum

B. bifidum

2 B. pseudolongum

2 B. longum

From pigs

12 Bifidobacterium species P1

${ }^{a}$ Of the 732 strains examined, there were $251 B$. adolescentis, 239 B. longum, $169 B$. catenulatum, $21 \mathrm{~B}$. bifidum, $10 \mathrm{~B}$. breve, and 5 $B$. dentium, from adult humans and $12 B$. thermopbilum from pigs. There were 25 additional isolates from humans that, according to both fermentation reactions and electrophoretic patterns, belonged to three undescribed species.

${ }^{b}$ Number of strains.

terium, these four species are gram-positive, nonsporeforming, nonmotile, non-proteolytic, fermentative, and anaerobic to aerotolerant rods that produce acetic, formic, and lactic acids. They do not produce catalase or gas. The optimum temperature for growth is between 30 and $45^{\circ} \mathrm{C}$.

The known sources of these species are listed in Table 1. The DNA homology relationships of these species to other species in the genus are given in Table 2 . The biochemical reactions of the type strain and other strains of each of these species are listed in Table 5.

$B$. coryneforme (ex Scardovi and Trovatelli 1969) sp. nov., nom. rev. (cor.v.ne.for'me. Gr. n. coryne a club; L. n. forma shape, form; M.L. adj. coryneformis club shaped). Cells of the type strain in prereduced anaerobically sterilized peptone-yeast extract-glucose broth (5) are 0.7to $1.2-\mu \mathrm{m}$ by $0.9-$ to $3.0-\mu \mathrm{m}$, coccoid, oval, or club-shaped rods that occur singly, in pairs, and in clumps.

Colonies on blood agar plates incubated anaerobically for $48 \mathrm{~h}$ at $37^{\circ} \mathrm{C}$ are punctiform to 1 $\mathrm{mm}$ in diameter, circular, entire, convex, translucent to semiopaque, grayish white, shiny, and smooth.

Growth in broth with a fermentable carbohydrate produces dense turbidity with a smooth or "cottony" sediment and a final pH of 4.3 to 5.3 . Slight turbidity and a small amount of sediment are produced in peptone-yeast extract broth that does not contain a fermentable carbohydrate. Other characteristics of the type strain and other strains of this species are given in Tables 1 through 3 and 5, in Fig. 10 and 13, and by Scardovi and Trovatelli (25).

The type strain, ATCC 25911, was isolated from the intestine of a bee.

B. globosum (ex Scardovi, Trovatelli, Crociani, and Sgorbati 1969) sp. nov., nom. rev. (glo.bo' sum. L. adj. globosus globelike, referring to the oval and round cells that are produced in some cultures). Cells of the type strain in peptoneyeast extract-glucose broth cultures are oval rods that are 1.4 to 1.5 by 1.5 to $2.8 \mu \mathrm{m}$ and occur in pairs, short chains, and clumps. Cells from colonies on the surface of blood agar incubated anaerobically, in air with $10 \% \mathrm{CO}_{2}$, or in candle jars are longer and often club shaped.

Colonies on the surface of blood agar are punctiform, circular, entire, convex, gray or white, shiny, and smooth.

Heavy turbidity and a "breadcrumb" sediment are produced in peptone-yeast extract broth containing a fermentable carbohydrate. The final $\mathrm{pH}$ is 4.1 to 4.6 . Slight turbidity is produced in peptone-yeast extract broth containing carbohydrates that are not fermented.

Other characteristics of the type strain and other strains of this species are given in Tables 1, 2, and 5, in Fig. 6 and 13, and by Scardovi et al. (28).

The type strain, ATCC 25865, was isolated from bovine rumen contents.

B. minimum sp. nov. (min'i.mum. L. adj. minimus least, referring to the small size of the cells). This taxon previously was referred to as the "minimum" homology group of Scardovi and Trovatelli (26).

Cells of the type strain in peptone-yeast extract or peptone-yeast extract-glucose broth cultures are 0.5 - to $0.6-\mu \mathrm{m}$ by 0.5 - to $2.8-\mu \mathrm{m}$, oval, club-shaped, or short rods that occur in short chains and in clumps. 
TABLE 5. Fermentation patterns of 999 Bifidobacterium strains examined ${ }^{a}$

\begin{tabular}{|c|c|c|c|c|c|c|c|c|c|c|c|c|c|c|c|c|c|c|c|c|c|}
\hline \multirow[b]{2}{*}{ Substrate } & \multicolumn{4}{|c|}{ B. adolescentis } & \multicolumn{3}{|c|}{ B. angulatum } & \multicolumn{4}{|c|}{ B. animalis } & \multirow{2}{*}{$\begin{array}{l}\begin{array}{c}\text { B. aster- } \\
\text { oides }\end{array} \\
\text { ATCC } \\
25910 \\
\text { (type) }\end{array}$} & \multicolumn{4}{|c|}{ B. bifidum } & \multirow{2}{*}{$\begin{array}{l}\text { B. boum } \\
\text { ATCC } \\
27917 \\
\text { (type) }\end{array}$} & \multicolumn{4}{|c|}{ B. breve } \\
\hline & $\begin{array}{l}\text { ATCC } \\
15703 \\
\text { (type) }\end{array}$ & & $\begin{array}{l}\text { Othe } \\
\text { strain } \\
+W\end{array}$ & er & $\begin{array}{l}\text { ATCC } \\
27535 \\
\text { (type) }\end{array}$ & & $\begin{array}{l}\text { ther } \\
\text { rains } \\
\text { W } \\
\end{array}$ & $\begin{array}{l}\text { ATCC } \\
25527 \\
\text { (type) }\end{array}$ & $\begin{array}{r}\mathrm{O} \\
\mathrm{str} \\
\mathrm{A}+\end{array}$ & $\begin{array}{l}\text { the } \\
\text { rain } \\
W\end{array}$ & & & $\begin{array}{l}\text { ATCC } \\
25921 \\
\text { (type) }\end{array}$ & $\begin{array}{r}\mathrm{C} \\
\mathrm{At} \\
\mathrm{A}\end{array}$ & $\begin{array}{l}\text { Othe } \\
\text { train } \\
\text { W }\end{array}$ & & & $\begin{array}{l}\text { ATCC } \\
15700 \\
\text { (type) } \\
\end{array}$ & & $\begin{array}{l}\text { ther } \\
\text { rains } \\
\text { W }\end{array}$ & \\
\hline Amygdalin & A & 274 & 8 & 22 & $\mathrm{~A}$ & 1 & 13 & - & 4 & 0 & 3 & $\mathrm{~A}$ & - & 0 & 13 & 37 & - & $\mathrm{A}$ & 16 & 6 & 6 \\
\hline Arabinose & A & 147 & 22 & 135 & A & 5 & 00 & A & 2 & 1 & 4 & A & - & 0 & 03 & 38 & & - & 1 & & 26 \\
\hline Cellobiose & A & 287 & 3 & 14 & A & 5 & 0 & - & 5 & 0 & 2 & A & - & 1 & 03 & 37 & - & A & 24 & 4 & 0 \\
\hline Esculin $\mathrm{pH}$ & A & 43 & 44 & $53^{c}$ & A & 4 & 1 & - & 0 & 0 & 7 & $\mathrm{~A}^{d}$ & - & 0 & 03 & 38 & - & W & & 11 & 8 \\
\hline Hydrolysis & + & 302 & 2 & 0 & + & 5 & 0 & + & 3 & 1 & 3 & + & - & 3 & 23 & 33 & W & + & 28 & 0 & 0 \\
\hline Glycogen & - & 277 & 1 & 26 & A & 4 & 01 & - & 0 & 0 & 7 & - & - & 0 & 03 & 38 & A & A & 23 & 1 & 4 \\
\hline Lactose & A & 303 & 1 & 0 & $\Lambda$ & 5 & 00 & A & 7 & 0 & 0 & $\mathrm{~A}-$ & A & 37 & 1 & 0 & - & A & 28 & 0 & 0 \\
\hline Maltose & A & 304 & 0 & 0 & A & 5 & 00 & A & 7 & 0 & 0 & $\mathrm{~A}-$ & - & 4 & 43 & 30 & A & A & 28 & 0 & 0 \\
\hline Mannitol & A & 143 & 2 & 159 & - & 3 & 02 & - & 0 & 0 & 7 & - & - & 0 & 03 & 38 & - & A & 23 & 0 & 5 \\
\hline Mannose & W & 141 & 13 & 150 & W & 0 & 05 & - & 6 & 0 & 1 & A & - & 1 & 13 & 36 & - & A & 18 & 9 & 1 \\
\hline Melezitose & - & 25 & 2 & 277 & - & 0 & 0 & - & 0 & 0 & 7 & A & - & 0 & 03 & 38 & - & - & 7 & 12 & \\
\hline Melibiose & A & 298 & 1 & 5 & A & 5 & 0 & A & 7 & 0 & 0 & A & A & 4 & 33 & 31 & A & A & 27 & 1 & 0 \\
\hline Raffinose & A & 301 & 1 & 2 & A & 5 & 0 & A & 7 & 0 & 0 & A & A & 3 & 03 & 35 & A & A & 28 & 0 & 0 \\
\hline Rhamnose & - & 22 & 4 & 278 & - & 0 & 05 & - & 0 & 0 & 7 & - & - & 0 & 03 & 38 & - & - & 0 & 12 & \\
\hline Ribose & A & 139 & 7 & 158 & W & 2 & 0 & W & 5 & 0 & 2 & W & - & 0 & 03 & 38 & - & W & 15 & 31 & 10 \\
\hline Salicin & A & 291 & 4 & 9 & A & 5 & 00 & - & 5 & 0 & 2 & A & - & 0 & 03 & 38 & - & A & 20 & 1 & \\
\hline Sorbitol & A & 186 & 3 & 115 & W & 4 & $\begin{array}{ll}0 & 1\end{array}$ & - & 0 & 0 & 7 & - & - & 0 & 03 & 38 & - & A & 22 & 0 & 6 \\
\hline Starch $\mathrm{pH}$ & $\mathrm{A}$ & 281 & 1 & 22 & A & 5 & 00 & A & 3 & 1 & 3 & - & - & 1 & 13 & 36 & A & A & 25 & 2 & 1 \\
\hline Hydrolysis & + & 156 & 5 & $8^{C}$ & + & 5 & 00 & - & 0 & 0 & 7 & - & - & 0 & 03 & $37^{c}$ & + & + & 24 & 0 & 4 \\
\hline Sucrose & $\mathrm{A}$ & 285 & 1 & 18 & A & 5 & 0 & A & 7 & 0 & 0 & A & - & 4 & 23 & 32 & A & $\mathrm{A}$ & 28 & 0 & 0 \\
\hline Trehalose & - & 157 & 5 & 142 & - & 1 & 04 & - & 0 & 0 & 7 & - & - & 0 & 03 & 38 & - & - & 3 & 22 & \\
\hline Xylose & A & 199 & 25 & 80 & A & 5 & $0 \mathrm{C}$ & A & 6 & 0 & 1 & A & - & 0 & 03 & 38 & - & - & 1 & 12 & 26 \\
\hline
\end{tabular}

TABLE 5. Continued

\begin{tabular}{|c|c|c|c|c|c|c|c|c|c|c|c|c|c|c|c|c|c|c|c|}
\hline \multirow[b]{2}{*}{ Substrate } & \multicolumn{4}{|c|}{ B. catenulatum } & \multirow{2}{*}{$\begin{array}{l}\text { B. choe- } \\
\text { rinum }\end{array}$} & \multicolumn{4}{|c|}{ "B. coryneforme" } & \multirow{2}{*}{$\begin{array}{l}\text { B. cuni- } \\
\text { culi } \\
\text { ATCC } \\
27916 \\
\text { (type) }\end{array}$} & \multicolumn{4}{|c|}{ B. dentium } & \multicolumn{4}{|c|}{ "B. globosum" } & \multirow{2}{*}{$\begin{array}{l}\text { B. indi- } \\
\text { cum } \\
\text { ATCC } \\
25912 \\
\text { (type) }\end{array}$} \\
\hline & $\begin{array}{l}\text { ATCC } \\
27539 \\
\text { (type) }\end{array}$ & \multicolumn{3}{|c|}{$\begin{array}{c}\text { Other } \\
\text { strains }\end{array}$} & & $\begin{array}{l}\text { ATCC } \\
25911 \\
\text { (type) }\end{array}$ & \multicolumn{3}{|c|}{$\begin{array}{l}\text { Other } \\
\text { strains }\end{array}$} & & $\begin{array}{l}\text { ATCC } \\
27534 \\
\text { (type) }\end{array}$ & \multicolumn{3}{|c|}{$\begin{array}{l}\text { Other } \\
\text { strains }\end{array}$} & $\begin{array}{l}\text { ATCC } \\
25865 \\
\text { (type) }\end{array}$ & \multicolumn{3}{|c|}{$\begin{array}{r}\text { Other } \\
\text { strains }\end{array}$} & \\
\hline Amygdalin & W & 168 & 16 & 12 & - & A & 2 & 0 & 1 & A & A & 50 & 8 & 3 & - & 0 & 0 & 9 & A \\
\hline Arabinose & A & 123 & 11 & 62 & - & A & 3 & 0 & 0 & A & A & 60 & 1 & 0 & A & 9 & 0 & 0 & A \\
\hline Cellobiose & A & 174 & 6 & 16 & - & A & 3 & 0 & 0 & A & A & 60 & 1 & 0 & - & 3 & 1 & 5 & A \\
\hline Esculin pH & A & 31 & 54 & $70^{c}$ & - & W & 1 & 0 & 2 & - & A & 28 & 121 & $14^{c}$ & - & 0 & 0 & 9 & - \\
\hline Hydrolysis & + & 188 & 6 & 2 & w & + & 2 & 1 & 0 & + & + & 52 & 3 & 6 & W & 5 & 1 & 3 & + \\
\hline Glycogen & A & 121 & 1 & 74 & A & - & 0 & 0 & 3 & A & A & 59 & 0 & 2 & $\mathrm{~A}$ & 9 & 0 & 0 & - \\
\hline Lactose & A & 196 & 0 & 0 & A & A & 3 & 0 & 0 & - & A & 61 & 0 & 0 & $\Lambda$ & 9 & 0 & 0 & A \\
\hline Maltose & A & 196 & 0 & 0 & A & A & 3 & 0 & 0 & A & A & 61 & 0 & 0 & A & 9 & 0 & 0 & A \\
\hline Mannitol & - & 39 & 0 & 157 & - & - & 0 & 0 & 3 & - & A & 54 & 1 & 6 & - & 0 & 0 & 9 & - \\
\hline Mannose & - & 106 & 19 & 71 & - & - & 0 & 0 & 3 & A & A & 61 & 0 & 0 & - & 3 & 1 & 5 & A \\
\hline Melezitose & - & 9 & 2 & 185 & - & - & 1 & 0 & 2 & - & A & 45 & 8 & 8 & - & 0 & 0 & 9 & - \\
\hline Melibiose & A & 191 & 3 & 2 & A & A & 3 & 0 & 0 & - & A & 61 & 0 & 0 & A & 9 & 0 & 0 & A \\
\hline Raffinose & A & 194 & 1 & 1 & A & A & 2 & 0 & 1 & - & A & 61 & 0 & 0 & A & 9 & 0 & 0 & A \\
\hline Rhamnose & - & 1 & 0 & 195 & - & - & 0 & 0 & 3 & - & W & 1 & 124 & 48 & - & 0 & 0 & 9 & - \\
\hline Ribose & - & 99 & 16 & 81 & - & - & 0 & 1 & 2 & - & A & 53 & 4 & 4 & W & 5 & 0 & 4 & A \\
\hline Salicin & A & 181 & 2 & 13 & - & A & 2 & 0 & 1 & A & A & 61 & 0 & 0 & - & 3 & 2 & 4 & A \\
\hline Sorbitol & A & 180 & 0 & 16 & - & - & 1 & 0 & 2 & - & - & 1 & 65 & 54 & - & 0 & 0 & 9 & - \\
\hline Starch $\mathrm{pH}$ & - & 157 & 23 & 16 & A & - & 0 & 0 & 3 & A & A & 61 & 0 & 0 & A & 9 & 0 & 0 & - \\
\hline Hydrolysis & - & 122 & 5 & $47^{c}$ & + & - & 0 & 0 & 3 & + & + & 61 & 0 & 0 & + & 9 & 0 & 0 & - \\
\hline Sucrose & $\mathrm{A}$ & 191 & 0 & 5 & A & A & 3 & 0 & 0 & A & A & 61 & 0 & 0 & A & 9 & 0 & 0 & A \\
\hline Trehalose & - & 134 & 3 & 59 & - & - & 0 & 0 & 3 & - & A & 56 & 4 & 1 & - & 0 & 0 & 9 & - \\
\hline Xylose & A & 135 & 9 & 52 & - & A & 3 & 0 & 0 & A & A & 61 & 0 & 0 & A & 9 & 0 & 0 & A \\
\hline
\end{tabular}

Surface colonies in prereduced anaerobically sterilized agar streak tubes are $1 \mathrm{~mm}$ in diameter; circular; entire; convex; translucent; gray, white, or buff; shiny; and smooth.

Cultures in broth with a fermentable carbohydrate produce dense turbidity with a flocculent sediment and a final $\mathrm{pH}$ of 4.1 to 4.4. Little or no growth is produced without a fermentable carbohydrate.
Other characteristics of the type strain and other strains of this species are given in Tables 1, 2, and 5, in Fig. 11 and 12, and by Scardovi and Trovatelli (26).

The type strain, ATCC 27538, was isolated from wastewater.

B. subtile sp. nov. (sub'ti.le. L. adj. subtilis slender, referring to the slender cells). This taxon previously was referred to as the "sub- 
TABLE 5. Continued

\begin{tabular}{|c|c|c|c|c|c|c|c|c|c|c|c|c|c|c|c|c|}
\hline \multirow[b]{2}{*}{ Substrate } & \multicolumn{2}{|c|}{ B. infantis } & \multicolumn{3}{|c|}{$\begin{array}{l}\text { "B. infantis" } \\
\text { longum" }\end{array}$} & \multicolumn{4}{|c|}{ B. longum } & \multicolumn{4}{|c|}{ B. magnum } & \multicolumn{2}{|c|}{ "B. minimum" } & \multirow{2}{*}{ 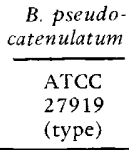 } \\
\hline & $\begin{array}{l}\text { ATCC } \\
15697 \\
\text { (type) }\end{array}$ & $\begin{array}{c}\text { Other } \\
\text { strains } \\
\mathrm{A}+\mathrm{W}-\end{array}$ & \multicolumn{3}{|c|}{$\begin{array}{l}\text { Strains } \\
A+W-\end{array}$} & $\begin{array}{l}\text { ATCC } \\
15707 \\
\text { (type) }\end{array}$ & \multicolumn{3}{|c|}{$\begin{array}{c}\text { Other } \\
\text { strains }\end{array}$} & $\begin{array}{l}\text { ATCC } \\
27540 \\
\text { (type) }\end{array}$ & \multicolumn{3}{|c|}{$\begin{array}{l}\text { Other } \\
\text { strains }\end{array}$} & $\begin{array}{l}\text { ATCC } \\
27538 \\
\text { (type) }\end{array}$ & $\begin{array}{l}\text { Other } \\
\text { strain }\end{array}$ & \\
\hline Amygdalin & - & 4312 & 1 & 0 & 4 & - & 85 & 36 & 151 & - & 0 & 0 & 2 & - & - & A \\
\hline Arabinose & - & 0118 & 5 & 0 & 0 & A & 260 & 5 & 7 & A & 2 & 0 & 0 & - & - & A \\
\hline Cellobiose & $w$ & 3115 & 0 & 1 & 4 & - & 44 & 13 & 215 & - & 0 & 0 & 2 & - & - & A \\
\hline Esculin pH & - & $\begin{array}{lll}0 & 1 & 18\end{array}$ & 3 & 1 & 1 & - & 29 & 21 & $121^{c}$ & - & 0 & 0 & 2 & - & - & A \\
\hline Ilydrolysis & + & $125 \quad 2$ & 2 & 2 & 1 & + & 105 & 15 & 152 & - & 0 & 0 & 2 & - & - & + \\
\hline Gilycogen & $\mathrm{A}$ & $\begin{array}{lll}0 & 0 & 19\end{array}$ & 0 & 0 & 5 & - & 5 & 3 & 264 & - & 0 & 0 & 2 & A & A & A \\
\hline Lactose & A & 1900 & 5 & 0 & 0 & A & 272 & 0 & 0 & A & 2 & 0 & 0 & - & - & A \\
\hline Maltose & - & 1900 & 5 & 0 & 0 & A & 271 & 1 & 0 & A & 2 & 0 & 0 & A & A & A \\
\hline Mannitol & - & $\begin{array}{lll}2 & 0 & 17\end{array}$ & 2 & 0 & 3 & - & 11 & 1 & 260 & - & 0 & 0 & 2 & - & - & - \\
\hline Mannose & W & 1612 & 5 & 0 & 0 & W & 149 & 25 & 98 & - & 0 & 0 & 2 & - & - & A \\
\hline Mclezitose & - & $\begin{array}{llll}0 & 0 & 19\end{array}$ & 0 & 0 & 5 & $A$ & 220 & 52 & 0 & - & 0 & 0 & 2 & - & - & - \\
\hline Melibiose & $\mathrm{A}$ & 1900 & 5 & 0 & 0 & $A$ & 270 & 1 & 1 & A & 1 & 1 & 0 & - & - & A \\
\hline Raffinose & A & 1900 & 5 & 0 & 0 & A & 266 & 3 & 3 & $A$ & 2 & 0 & 0 & - & - & A \\
\hline Rhamnose & - & $\begin{array}{llll}0 & 0 & 19\end{array}$ & 0 & 0 & 5 & - & 3 & 0 & 269 & - & 0 & 0 & 2 & - & - & -- \\
\hline Ribose & A & 739 & 3 & 0 & 2 & A & 159 & 8 & 105 & $\mathrm{~A}$ & 2 & 0 & 0 & - & - & $\mathrm{A}$ \\
\hline Salicin & $\mathrm{A}$ & $\begin{array}{lll}5 & 1 & 13\end{array}$ & 2 & 1 & 2 & - & 64 & 8 & 200 & - & 0 & 0 & 2 & - & - & $\mathrm{A}$ \\
\hline Sorbitol & - & $\begin{array}{lll}2 & 0 & 17\end{array}$ & 0 & 0 & 5 & - & 10 & 0 & 262 & - & 0 & 0 & 2 & - & - & $\mathrm{A}$ \\
\hline Starch pH & $\mathrm{A}$ & 3016 & 1 & 4 & 0 & $A$ & 115 & 67 & 90 & A & 1 & 1 & 0 & $\mathrm{~A}$ & $\mathrm{~A}$ & $A$ \\
\hline Hydrolysis & + & $\begin{array}{lll}2 & 0 & 17\end{array}$ & 0 & 1 & 4 & - & 33 & 8 & $159^{c}$ & - & 0 & 0 & 2 & + & + & + \\
\hline Sucrose & $A$ & 1900 & 5 & 0 & 0 & A & 267 & 5 & 0 & $\Lambda$ & 2 & 0 & 0 & - & $\mathrm{A}$ & $\mathrm{A}$ \\
\hline Trehalose & - & 2116 & 2 & 0 & 3 & - & 33 & 8 & 231 & - & 0 & 0 & 2 & - & - & A \\
\hline Xylose & - & $\begin{array}{lll}10 & 0 & 9\end{array}$ & 5 & 0 & 0 & A & 267 & 5 & 0 & A & 2 & 0 & 0 & - & - & A \\
\hline
\end{tabular}

TABLE 5. Continued

\begin{tabular}{|c|c|c|c|c|c|c|c|c|c|c|c|c|c|c|c|c|c|}
\hline \multirow[b]{2}{*}{ Substrate } & \multicolumn{4}{|c|}{$\begin{array}{l}\text { B. pseudo- } \\
\text { longum }\end{array}$} & \multirow{2}{*}{$\begin{array}{l}\text { B. pul } \\
\text { lorum }\end{array}$} & \multicolumn{4}{|c|}{ "B. subtile" } & \multicolumn{4}{|c|}{ B. suis } & \multicolumn{4}{|c|}{$\begin{array}{l}\text { B. tbermo- } \\
\text { pbilum }\end{array}$} \\
\hline & $\begin{array}{l}\text { ATCC } \\
25526 \\
\text { (type) }\end{array}$ & & $\begin{array}{l}\text { ther } \\
\text { rains } \\
\text { W }\end{array}$ & & & $\begin{array}{l}\text { ATCC } \\
27537 \\
\text { (type) }\end{array}$ & & $\begin{array}{l}\text { the } \\
\text { rain } \\
W\end{array}$ & & $\begin{array}{l}\text { ATCC } \\
27533 \\
\text { (type) }\end{array}$ & & $\begin{array}{l}\text { ther } \\
\text { rains } \\
W\end{array}$ & & $\begin{array}{l}\text { ATCC } \\
25525 \\
\text { (type) }\end{array}$ & & $\begin{array}{l}\text { the } \\
\text { rain } \\
\text { W }\end{array}$ & $\begin{array}{l}\text { er } \\
\text { ns }\end{array}$ \\
\hline Amygdalin & - & 0 & 0 & 3 & - & - & 0 & 0 & 4 & - & 0 & 0 & 3 & - & 0 & 0 & 15 \\
\hline Arabinose & $\mathrm{A}$ & 3 & 0 & 0 & - & - & 0 & 0 & 4 & A & 3 & 0 & 0 & - & 0 & 0 & 15 \\
\hline Cellobiose & - & 2 & 0 & 1 & A & A & 2 & 0 & 2 & - & 0 & 0 & 3 & - & 1 & 0 & 14 \\
\hline Esculin pH & - & 1 & 0 & 2 & A & $w$ & 0 & 0 & 4 & W & 1 & 1 & 1 & - & 1 & 0 & 14 \\
\hline Hydrolysis & + & 2 & 0 & 1 & + & + & 2 & 2 & 0 & + & 3 & 0 & 0 & + & 9 & 0 & 6 \\
\hline Glycogen & A & 2 & 0 & 1 & - & A & 3 & 0 & 1 & - & 0 & 0 & 3 & A & 14 & 0 & 1 \\
\hline Lactose & $\mathrm{A}$ & 3 & 0 & 0 & & W-- & 0 & 0 & 4 & A & 3 & 0 & 0 & - & 1 & 0 & 14 \\
\hline Maltose & A & 3 & 0 & 0 & A & A & 3 & 0 & 1 & A & 3 & 0 & 0 & A & 15 & 0 & 0 \\
\hline Mannitol & - & 0 & 0 & 3 & - & - & 0 & 0 & 4 & - & 0 & 0 & 3 & $\ldots$ & 0 & 0 & 15 \\
\hline Mannose & - & 1 & 0 & 2 & A & - & 0 & 0 & 4 & A & 3 & 0 & 0 & - & 0 & 0 & 15 \\
\hline Melezitose & - & 0 & 0 & 3 & A & A & 3 & 0 & 1 & - & 0 & 0 & 3 & $\ldots$ & 0 & 0 & 15 \\
\hline Melibiose & A & 3 & 0 & 0 & A & A & 4 & 0 & 0 & $A$ & 3 & 0 & 0 & A & 15 & 0 & 0 \\
\hline Raffinose & $\mathrm{A}$ & 3 & 0 & 0 & $\mathrm{~A}$ & $\mathrm{~A}$ & 4 & 0 & 0 & A & 3 & 0 & 0 & $\Lambda$ & 15 & 0 & 0 \\
\hline Rhamnose & - & 0 & 0 & 3 & - & - & 0 & 0 & 4 & - & 0 & 0 & 3 & - & 0 & 0 & 15 \\
\hline Ribose & A & 3 & 0 & 0 & $A$ & $A-$ & 1 & 1 & 2 & - & 1 & 0 & 2 & - & 0 & 0 & 15 \\
\hline Salicin & A & 3 & 0 & 0 & $A$ & $A-$ & 1 & 1 & 2 & - & 0 & 0 & 3 & $\Lambda$ & 2 & 0 & 13 \\
\hline Sorbitol & - & 0 & 1 & 2 & - & - & 4 & 0 & 0 & - & 0 & 0 & 3 & - & 0 & 0 & 15 \\
\hline Starch pH & $\Lambda$ & 3 & 0 & 0 & - & A & 3 & 0 & 1 & - & 0 & 1 & 2 & A & 15 & 0 & 0 \\
\hline Hydrolysis & + & 2 & 0 & 1 & - & + & 3 & 0 & 1 & - & 0 & 0 & 3 & + & 8 & 0 & 7 \\
\hline Sucrose & A & 3 & 0 & 0 & A & A & 4 & 0 & 0 & A & 3 & 0 & 0 & A & 15 & 0 & 0 \\
\hline Trehalose & - & 0 & 0 & 3 & A & - & 1 & 0 & 3 & - & 0 & 0 & 3 & - & 0 & 0 & 15 \\
\hline Xylose & A & 3 & 0 & 0 & A & - & 0 & 0 & 4 & A & 3 & 0 & 0 & - & 0 & 0 & 15 \\
\hline
\end{tabular}

tile" homology group of Scardovi and Trovatelli (26).

Cells of the type strain in peptone-yeast extract-glucose broth cultures are $0.8-$ by $2.1-\mu \mathrm{m}$ to $4.5-\mu \mathrm{m}$, straight or bent rods that occur singly or in pairs. Longer, branching, bifid, knobbed, and club-shaped forms in tangled masses are produced in semisolid thioglycolate medium. Smaller coccoid and rod-shaped cells that occur in short chains are produced in broth media that do not contain fermentable carbohydrates.

Colonies on the surface of blood agar incubat- 
TABLE 6. Key for differentiation of major Bifidobacterium species of human origin

\begin{tabular}{|c|c|c|c|c|}
\hline \multicolumn{4}{|c|}{ Substrate } & \multirow{2}{*}{ Suggested species } \\
\hline \multicolumn{4}{|c|}{ Melezitose Glycogen Xylose Rhamnose } & \\
\hline \multirow[t]{8}{*}{$+^{a}$} & + & + & A & (B. adolescentis, $B$. dentium $)^{b}$ \\
\hline & & & - & B. dentium (B. adolescentis, $B$. catenulatum $)^{c}$ \\
\hline & & - & A & (B. adolescentis) \\
\hline & & & - & (B. adolescentis, B. breve, B. catenulatum) \\
\hline & - & + & A & (B. adolescentis) \\
\hline & & & - & B. longum (B. adolescentis, B. catenulatum) \\
\hline & & - & A & ( $B$. adolescent is) \\
\hline & & & - & (B. adolescentis, $B$. breve, $B$. catenulatum) \\
\hline \multirow[t]{8}{*}{-} & + & + & A & (B. adolescentis, B. dentium) \\
\hline & & & - & B. adolescentis, B. catenulatum, B. globosum (B. dentium) \\
\hline & & - & A & (B. adolescentis) \\
\hline & & & - & B. breve (B. adolescentis, $B$. catenulatum) \\
\hline & - & + & A & (B. adolescentis) \\
\hline & & & - & $B$. infantis (B. adolescentis, B. catenulatum) \\
\hline & & - & A & (B. adolescentis) \\
\hline & & & - & $\begin{array}{l}\text { B. bifidum, }{ }^{d} \text { B. infantis (B. adolescentis, B. breve, } \\
\text { B. catenulatum) }\end{array}$ \\
\hline
\end{tabular}

$a_{+}=$Acid or weak acid, $\mathrm{A}=$ acid, $-=$ not fermented.

${ }^{b}$ Species in parentheses are less likely possibilities.

${ }^{c}$ Because we were unable to differentiate $B$. catenulatum and $B$. pseudocatenulatum by protein patterns, the reactions listed here and in Table 5 may represent both species. Scardovi et al. (27) indicate that starch- and dextrin-positive strains are B. pseudocatenulatum, while starch- and dextrin-negative reactions correlate with strains that are $B$. catenulatum by DNA homology.

$d_{\text {Amygdalin, arabinose, and cellobiose all negative }=B . \text { bifidum } .}$.

ed anaerobically are punctiform to $1 \mathrm{~mm}$ in diameter, circular, entire, slightly raised, translucent, colorless, shiny, and smooth. Similar (but smaller) colonies are produced on blood agar incubated in a candle jar.

Dense turbidity with a granular or flocculent sediment and a final $\mathrm{pH}$ of 4.1 to 4.8 are produced in peptone-yeast extract broth containing fermentable carbohydrates. Slight to moderate turbidity is produced in peptone-yeast extract broth containing carbohydrates that are not fermented.

Other characteristics of the type strain and other strains of this species are given in Tables
1,2 , and 5 , in Fig. 11 and 12, and by Scardovi and Trovatelli (26).

The type strain, ATCC 27537, was isolated from wastewater.

\section{ACKNOWLEDGMENTS}

We thank Elizabeth P. Cato, Don E. Hash, Lillian V. Holdeman, Ruth Z. Beyer, and Dianne M. Wall for assistance with the culture preparations and analyses and D. Matteuzzi for sending reference cultures.

We also thank the Commonwealth of Virginia and the National Institute of Allergy and Infectious Diseases (Public Health Service grant AI 15244-02A1) for financial support of the research and the Consiglio Nazionale delle Ricerche, Rome, Italy, for the study grant for B.B. to carry out this 
project at the Anaerobe Laboratory, Virginia Polytechnic Institute and State University.

\section{REPRINT REQUESTS}

Address reprint requests to: Dr. W. E. C. Moore, Department of Anaerobic Microbiology, Virginia Polytechnic Institute and State University, Blacksburg, VA 24061.

\section{LITERATURE CITED}

1. Fox, R. H., and D. E. McClain. 1974. Evaluation of the taxonomic relationship of Micrococcus cryophilus, Branhamella catarrhalis, and neisseriae by comparative polyacrylamide gel electrophoresis of soluble proteins. Int. J. Syst. Bacteriol. 24:172-176.

2. Georg, L. K., G. W. Robertstad, S. A. Brinkman, and M. D. Hicklin. 1965. A new pathogenic anaerobic Actinomyces species. J. Infect. Dis. 115:88-99.

3. Gherna, R. L., and P. Pienta. 1980. Bifdobacterium bifdum, p. 50. In American Type Culture Collection catalogue of strains I, 14 th ed. American Type Culture Collection, Rockville, Md.

4. Gross, C. S., D. A. Ferguson, Jr., and C. S. Cummins. 1978. Electrophoretic protein patterns and enzyme mobilities in anaerobic coryneforms. Appl. Environ. Microbiol. 35:1102-1108.

5. Holdeman, L. V., E. P. Cato, and W. E. C. Moore (ed.). 1977. Anaerobe laboratory manual, 4th ed. Anaerobe Laboratory, Virginia Polytechnic Institute and State University, Blacksburg.

6. Holdeman, L. V., I. J. Good, and W. E. C. Moore. 1976. Human fecal flora: variation in bacterial composition within individuals and a possible effect of emotional stress. Appl. Environ. Microbiol. 31:359-375.

7. Holdeman, L. V., and W. E. C. Moore (ed.). 1970. Outline of clinical methods in anaerobic bacteriology, 2nd revision. Anaerobe Laboratory, Virginia Polytechnic Institute and State University, Blacksburg.

8. Jarvis, A. W., and J. M. Wolff. 1979. Grouping of lactic streptococci by gel electrophoresis of soluble cell extracts. Appl. Environ. Microbiol. 37:391-398.

9. Kersters, K., and J. De Ley. 1975. Identification and grouping of bacteria by numerical analysis of their electrophoretic protein patterns. J. Gen. Microbiol. 87:333-342.

10. Matteuzzi, D., F. Crociani, G. Zani, and L. D. Trovatelli. 1971. Bifidobacterium suis n. sp.: a new species of the genus Bifidobacterium isolated from pig feces. Z. Allg. Mikrobiol. 11:387-395.

11. Mays, T. D., L. V. Holdeman, W. E. C. Moore, M. Rogosa, and J. L. Johnson. 1982. Taxonomy of the genus Veillonella Prévot. Int. J. Syst. Bacteriol. 32:28-36.

12. Mitsuoka, T. 1969 . Vergleichende Untersuchungen über die Bifidobakterien aus dem Verdauungstrakt von Menschen und Tieren. Zentralbl. Bakteriol. Parasitenkd. Infektionskr. Hyg. Abt. 1 Orig. 210:52-64.

13. Mitsuoka, T., Y. Morishita, A. Terada, and K. Watanabe. 1974. Actinomyces eriksonii Georg, Robertstad, Brinkman und Hicklin 1965 identisch mit Bifidobacterium adolescentis Reuter 1963. Zentralbl. Bakteriol. Parasitenkd. Infektionskr. Hyg. Abt. 1 Orig. Reihe A 226:257263.

14. Moore, W. E. C., E. P. Cato, I, J. Good, and L. V. Holdeman. 1981. The effect of diet on the human fecal flora, $p$. 11-23. In W. R. Bruce et al. (ed.), Cold Spring Harbor Banbury Report, vol. 7. Gastrointestinal cancer: endogenous factors. Cold Spring Harbor Laboratory, Cold Spring Harbor, N.Y.

15. Moore, W. E. C., D. E. Hash, L. V. Holdeman, and E. P. Cato. 1980. Polyacrylamide slab gel electrophoresis of soluble proteins for studies of bacterial floras. Appl. Environ. Microbiol. 39:900-907.

16. Moore, W. E. C., and L. V. Holdeman. 1974. Human fecal flora: the normal flora of 20 Japanese-Hawaiians. Appl. Microbiol. 27:961-979.
17. Orla-Jensen, S, 1924. La classification des bacteries lactiques. Lait 4:468-474.

18. Pine, L. 1970 . Classification and phylogenetic relationship of microaerophilic actinomycetes. Int. J. Syst. Bacteriol. 20:445-474.

19. Pine, L., and L. Georg. 1965. The classification and phylogenetic relationships of the Actinomycetales. Int. Bull. Bacteriol. Nomencl. Taxon. 15:143-163.

20. Pine, L., and A. Howell. 1956. Comparison of physiological and biochemical characters of Actinomyces spp. with those of Lactobacillus bifidus. J. Gen. Microbiol. 15:428445 .

21. Reuter, G. 1963-64. Vergleichende Untersuchungen über die Bifidus-Flora im Säuglings- und Erwachsenenstuhl. Zentralbl. Bakteriol. Parasitenkd. Infektionskr. Hyg. Abt. 1 Orig. 191:486-507.

22. Rogosa, M. 1974. Genus III. Bifidobacterium Orla-Jensen 1924 , 472, p. 669-676. In R. E. Buchanan and N. E. Gibbons (ed.), Bergey's manual of determinative bacteriology, 8th ed. The Williams \& Wilkins Co., Baltimore.

23. Scardovi, V., F. Casalicchio, and N. Vincenzi. 1979. Multiple electrophoretic forms of transaldolase and 6-phosphogluconic dehydrogenase and their relationships to the taxonomy and ecology of the bifidobacteria. Int. J. Syst. Bacteriol. 29:312-327.

24. Scardovi, V., and F. Crociani. 1974. Bifidobacterium catenulatum, Bifidobacterium dentium, and Bifidobacterium angulatum: three new species and their deoxyribonucleic acid homology relationships. Int. J. Syst. Bacteriol. 24:6-20.

25. Scardovi, V., and L. D. Trovatelli. 1969. New species of bifid bacteria from Apis mellifica L. and Apis indica F. A contribution to the taxonomy and biochemistry of the genus Bifidobacterium. Zentralbl. Bakteriol. Parasitenkd. Infektionskr. Hyg. Abt. 2 123:64-88.

26. Scardovi, V., and L. D. Trovatelli. 1974. Bifidobacterium animalis (Mitsuoka) comb. nov. and the "minimum" and "subtile" groups of new bifidobacteria found in sewage. Int. J. Syst. Bacteriol. 24:21-28.

27. Scardovi, V., L. D. Trovatelli, B. Biavati, and G. Zani. 1979. Bifidobacterium cuniculi, Bifidobacterium choerinum, Bifidobacterium boum, and Bifidobacterium pseudocatenulatum: four new species and their deoxyribonucleic acid homology relationships. Int. J. Syst. Bacteriol. 29:291-311.

28. Scardovi, V., L. D. Trovatelli, F. Crociani, and B. Sgorbati. 1969. Bifid bacteria in bovine rumen. New species of the genus Bifidobacterium: $B$. globosum $n$. sp. and $B$. ruminale n. sp. Arch. Mikrobiol. 68:278-294.

29. Scardovi, V., L. D. Trovatelli, G. Zani, F. Crociani, and D. Matteuzzi. 1971. Deoxyribonucleic acid homology relationships among species of the genus Bifidobacterium. Int. J. Syst. Bacteriol. 21:276-294.

30. Scardovi, V., and G. Zani. 1974. Bifidobacterium magnum sp. nov., a large, acidophilic bifidobacterium isolated from rabbit feces. Int. J. Syst. Bacteriol. 24:29-34.

31. Scardovi, V., G. Zani, and L. D. Trovatelli. 1970. Deoxyribonucleic acid homology among the species of the genus Bifidobacterium isolated from animals. Arch. Mikrobiol. 72:318-325.

32. Seiter, J. A., and J. M. Jay. 1980. Application of polyacrylamide gel electrophoresis to the characterization and identification of Arthrobacter species. Int. J. Syst. Bacteriol. 30:460-465.

33. Skerman, V. B. D., V. McGowan, and P. H. A. Sneath (ed.). 1980. Approved lists of bacterial names. Int. J. Syst. Bacteriol. 30:225-420.

34. Slack, J. M. 1974. Genus I. Actinomyces Harz 1877, 485 , p. 660-667. In R. E. Buchanan and N. E. Gibbons (ed.), Bergey's manual of determinative bacteriology, 8th ed. The Williams \& Wilkins Co., Baltimore.

35. Strom, A., J. K. Dyer, C. Marsh, and J. L. Tribble. 1976. Identification and characterization of species of the family Bacteroidaceae by polyacrylamide gel electrophoresis. J. Dent. Res. 55:252-256. 
36. Tissier, H. 1900. Recherches sur la flore intestinale des nourrissons. Paris Theses.

37. Trovatelli, L. D., F. Crociani, M. Pedinotti, and V. Scardovi. 1974. Bifidobacterium pullorum sp. nov.: a new species isolated from chicken feces and a related group of bifidobacteria isolated from rabbit feces. Arch. Microbiol. 98:187-198.

38. Zani, G., B. Biavati, F. Crociani, and D. Matteuzzi. 1974. Bifidobacteria from the faeces of piglets. J. Appl. Bacteriol. 37:537-547. 